\title{
Institutional proxy voting in South Africa: Process, outcomes and impact
}

\author{
S. Viviers ${ }^{a *}$ and E.vdM. Smit ${ }^{\mathrm{b} 1}$ \\ aDepartment of Business Management, Stellenbosch University, Private Bag X1, Matieland, 7602, South Africa \\ bUniversity of Stellenbosch Business School, PO Box 610, Bellville, 7535, South Africa \\ *To whom all correspondence should be addressed \\ sviviers@sun.ac.za
}

\begin{abstract}
This study investigated the nature of institutional shareholder activism in South Africa with a particular focus on proxy voting as a public form of shareholder discontent. A total of 24510 votes cast by 17 local investment management companies in 2013 were analysed. Interviews were also conducted with selected investment managers to gain more insight into the proxy voting process at their companies. Based on this data, it was concluded that investment managers preferred to engage with investee companies in private and viewed proxy voting as the last link in the shareholder activism chain. As a result, only 6.6 per cent of all votes were 'against' resolutions tabled by 347 JSE-listed companies in 2013. Resolutions regarding shareholders' endorsement of companies' remuneration policies; the election and re-election of directors, particularly those serving on audit committees; and the issuance of ordinary shares elicited the most opposition. Companies that were excluded from the JSE's Socially Responsible Investment Index in 2013 attracted significantly more opposition than their counterparts who were included in the index when seeking shareholder approval on the election and re-election of directors and the placing of shares under the control of directors. The same applied to companies that had low environmental, social and governance disclosure scores in 2013 as regards the issuance of shares. It is recommended, amongst others, that shareholder activism in South Africa be promoted by enhancing investor education and effecting some regulatory changes.
\end{abstract}

\section{Introduction}

"With great power comes great responsibility"

(Voltaire 1694 - 1778)

South Africa has been through remarkable political changes since 1994. Whilst most companies have implemented measures to promote social equality and environmental sustainability (Matthews, 2014), others are still unresponsive to stakeholders' calls for transformation. Although shareholder activism could be instrumental in changing corporate policies and practices (Wen, 2009; Thomas \& Cotter, 2007), shareholder activism is still uncommon in South Africa (Viviers, 2014).

As indicated in Figure 1, shareholder activism, also called 'active engagement', is one of three core strategies available to investors who wish to align their financial objectives with any environmental, social and governance (ESG) concerns they may have. Shareholder activists are essentially investors who use their equity stake in a company (called the investee company) to hold managers accountable on ethical and ESG considerations. They can do so by using a combination of private and public mechanisms.

Shareholder activism is generally seen as a long-term process (European SRI Study 2014; 2014), that is primarily undertaken by large institutional investors (Hadani, Goranova \& Khan, 2011; Poulsen, Strand, \& Thomsen, 2010; Sjöstrom,
2008). These investors' dominance as shareholder activists can be attributed to the fact that they have more incentives and resources to monitor managers' actions compared to those of individual investors (Gillan \& Starks, 2007, 2000).

It should be noted that the term 'institutional investor' is often loosely used to refer to asset owners and asset managers. Asset owners, who own ordinary shares in a company, have the right to vote on certain matters, such as the election and re-election of directors, mergers and acquisitions and proposed changes to the company's capital structure. Matters that require shareholder approval are formulated as resolutions and are tabled at the company's AGM. Asset owners typically delegate their voting power to asset managers (also called investment managers), hence reference being made to proxy voting. Shareholders can voice their discontent about matters by voting against resolutions or by submitting their own resolutions for consideration at the AGM. Shareholder resolutions are typically opposed by management, hence shareholders' insistence on a vote.

The first academic study on institutional shareholder activism in South Africa was conducted by Veicht (1995). Since then only limited research has been undertaken on the mechanisms used by local shareholder activists to. Given that researchers do not have access to data on private engagements between shareholders and investee companies, the primary objective of this study was thus to investigate proxy voting as a public shareholder activism mechanism. Aggarwal, Saffi and

\footnotetext{
${ }^{1}$ The financial assistance of the National Research Foundation (NRF) towards this research is hereby acknowledged. Opinions expressed and conclusions arrived at, are those of the authors and are not necessarily attributed to the NRF.
} 
Sturgess (2015) provide further justification for a study on proxy voting by arguing that it is one of the key mechanisms currently used by institutional investors to exert their influence on corporate decision-making. Secondary objectives were to gain some understanding of the causative factors behind voting behaviour and to provide practical recommendations to stimulate the broader adoption of shareholder activism in South Africa. Recommendations relevant to pension fund trustees, investment management companies, consultants, academics, and the South African regulator are put forward.

\begin{tabular}{|c|c|c|c|}
\hline \multicolumn{2}{|c|}{ Strategy } & Purpose of strategy & Mechanism \\
\hline \multirow{3}{*}{ Screening } & $\begin{array}{l}\text { Negative } \\
\text { screening }\end{array}$ & $\begin{array}{l}\text { Refraining from investing in } \\
\text { the securities of companies } \\
\text { producing 'undesirable' } \\
\text { products or services, as well as } \\
\text { those operating in 'undesirable' } \\
\text { industries and countries. }\end{array}$ & $\begin{array}{l}\text { Applying exclusionary investment } \\
\text { criteria. }\end{array}$ \\
\hline & $\begin{array}{l}\text { Positive } \\
\text { screening }\end{array}$ & $\begin{array}{l}\text { Investing in companies that are } \\
\text { deemed good corporate citizen; } \\
\text { i.e. those companies that are } \\
\text { proactive on managing ethical, } \\
\text { environmental, social and } \\
\text { corporate governance risks. }\end{array}$ & $\begin{array}{l}\text { Applying positive investment } \\
\text { criteria. }\end{array}$ \\
\hline & $\begin{array}{l}\text { Best-in-class } \\
\text { screening }\end{array}$ & $\begin{array}{l}\text { Investing in companies that are } \\
\text { deemed good corporate citizens } \\
\text { in selected industries. }\end{array}$ & $\begin{array}{l}\text { Applying exclusionary and positive } \\
\text { investment criteria. }\end{array}$ \\
\hline $\begin{array}{l}\text { Impact } / c \\
\text { empowerment } \\
\text { investing }\end{array}$ & $\begin{array}{l}\text { community / } \\
\text { cause-related }\end{array}$ & $\begin{array}{l}\text { Supporting particular causes by } \\
\text { investing directly in them. }\end{array}$ & $\begin{array}{l}\text { Providing equity and debt capital to } \\
\text { social enterprises and micro lenders. }\end{array}$ \\
\hline \multirow{2}{*}{$\begin{array}{l}\text { Shareholder } \\
\text { activism }\end{array}$} & $\begin{array}{l}\text { Private } \\
\text { activism }\end{array}$ & $\begin{array}{l}\text { Raising concerns with } \\
\text { companies in private. }\end{array}$ & $\begin{array}{l}\text { Writing letters, engaging in } \\
\text { confidential negotiations, initiating } \\
\text { legal proceeding and divesting, i.e. } \\
\text { selling all the shares owned in a } \\
\text { company that fails to respond to a } \\
\text { shareholder's requests. }\end{array}$ \\
\hline & $\begin{array}{l}\text { Public } \\
\text { activism }\end{array}$ & $\begin{array}{l}\text { Raising concerns } \\
\text { companies in public. }\end{array}$ & $\begin{array}{l}\text { Filing shareholder resolutions, } \\
\text { asking questions at annual general } \\
\text { meetings, voting 'against' } \\
\text { management resolutions and } \\
\text { stimulating public debate on issues } \\
\text { of concern. }\end{array}$ \\
\hline
\end{tabular}

Figure 1: Responsible investment strategies

Source: Adapted from Nordén \& Strand (2011); Morgan, Poulsen, Wolf \& Yang (2011); Cheng, Huang, Li \& Lobo (2010); Judge, Guar \& Muller-Kahle (2010); Admati \& Pfleiderer (2009); Kaempfer, Lehman \& Lowenberg (2009)

The remainder of the study is structured as follows: next, an in-depth discussion of the concept of institutional shareholder activism is provided, followed by an exposition of the methods used to collect and analyse data. Finally, the main findings are summarised and some recommendations put forward.

\section{Shareholder activism}

\section{The global context}

Religious groups in the United States (US) were the first shareholders to raise their human rights concerns in public in the 1940s (Proffitt \& Spicer, 2006). Public pension funds followed suit in the 1980s and were later joined by private pension funds and trade unions. A review of US studies suggests that, while many shareholder activists make extensive use of shareholder resolutions, the majority prefer to resolve issues in private. Willard, Carleton, Nelson and Weisbach (2002), for example, found that a large US financial institution reached agreements with targeted companies more than 95 per cent of the time. In the vast majority of these cases, the agreements were reached without shareholders voting on the resolution. Likewise, Bauer, Moers and Viehs (2012) attributed the withdrawal of shareholder resolutions in the US to successful private negotiations. They defined these successful negotiations as ones where both parties reached an amicable arrangement on how management should implement the shareholders' resolutions.

Legislation in the United Kingdom (UK) allows shareholders to use legal proceedings and shareholder resolutions to enforce their rights. However, as these measures are seen as "very public" or "very aggressive", they are rarely used by shareholder activists (Becht, Franks, Mayer \& Rossi, 2010). The general belief in the UK is that confidential and frank negotiations with investee companies result in the building of trust between shareholders and managers, thus resolving the issues.

\section{The South African context}

Despite claims that shareholder activism can be a lightning rod to "accelerate socio-economic transformation in South Africa" (Greenblo, 2014a), and Veitch's (1995: 52) conclusion that institutional investors "have tremendous clout", little is known about the role that institutional investors can play in promoting corporate change before it was highlighted in the second King report (King II) on corporate governance in South Africa, published in 2002. Legal experts, however, cautioned that any attempt to promote shareholder activism (as suggested in King II) should address the underlying reasons of shareholder apathy in the country (Rademeyer \& Holtzhausen, 2004). These reasons included a lack of access to company information, a lack of expertise to process company information, and failure to recognise the importance of shareholder activism and its associated costs. Similar barriers to shareholder activism have been noted in the international literature (Morgan et al., 2011; Sjöstrom, 2008). Despite shareholder engagement receiving more attention post-King II, only one investment manager employed an engagement overlay at the turn of the millennium (Viviers, 2014).

Although South African asset owners are legally permitted to file shareholder resolutions, very few do so (Silverman \& Duncan, 2014; Lekhesa, 2009). In an attempt to promote institutional shareholder activism in South Africa, the Association of Savings and Investments SA launched a Code for Responsible Investing in South Africa (CRISA) in 2011. This Code was developed in conjunction with the Institute of Directors Southern Africa and the Principal Officers Association. The Code incorporates the United Nations' Principles for Responsible Investment (PRI) and the recommendations of the third King report (King III) on 
corporate governance in South Africa (Code for Responsible Investing in South Africa, 2011).

Despite public support for the Code, a survey by the CRISA committee in 2013 revealed that few institutional investors seriously considered the principles (Responsible investment research - CRISA disclosure by institutional investors and their service providers, 2013). The committee's findings concur with Winfield's (2011: 2) claim that "only a handful of local investment managers are excited, passionate and serious about proxy voting and other means of stewardship".

\section{The effectiveness of proxy voting as a shareholder activism mechanism}

Several researchers have investigated the effectiveness of institutional shareholder activism in changing corporate behaviour (Chung \& Talaulicar, 2009; Wen, 2009). As researchers do not have access to data on private discussions between shareholders and investee companies, most studies on the effectiveness of shareholder activism focus on proxy voting and non-binding shareholder resolutions.

Karpoff, Malatesta and Walking (1996) and Gillan and Starks (2000) both reported that non-binding shareholder resolutions on executive compensation, the so-called 'say-on-pay' votes, appear to have no consistent effects on shareholder value. The authors contended that, although advisory say-on-pay votes do not affect corporate pay levels, they do cast a spotlight on companies with poor corporate governance. More recently, Conyon and Sadler (2010) and Armstrong, Gow and Larcker (2013) found that neither low voting support for, nor outright rejection of these executive remuneration plans had led to a decrease in the level and composition of CEO incentive compensation. In contrast, Ferri and Maber (2013) noted that UK firms responded to negative say-on-pay votes by removing controversial CEO pay practices. Increased support for shareholder resolutions in recent years has furthermore resulted in boards becoming more willing to remove antitakeover defences (Thomas \& Cotter, 2007), and to reform pollution management practices (Lee \& Lounsbury, 2011).

\section{Characteristics of companies targeted by shareholder activists}

The literature suggests that a number of factors contribute to the likelihood of a company being targeted by shareholder activists, be it in private or public. Clark and Hebb (2004) highlighted a home bias in private negotiations, showing that UK firms were more likely to be targeted by UK shareholder activists than were foreign firms. In contrast, Poulsen et al. (2010) noted that the prevalence of shareholder activism was higher in Swedish companies with more foreign ownership.

Rehbein, Waddock and Graves (2006) reported that shareholder activists in the US targeted companies producing controversial products (such as tobacco) and those with poor environmental practices. Studies by Morgan et al. (2011) and $\mathrm{Wu}$ (2004) also revealed that companies in specific industries were targeted due to poor employee and community relations and weak corporate governance policies and practices. Sparks and Cowton (2004) noted that shareholder resolutions on corporate social responsibility received around 25 per cent of votes cast in the 1990s. The authors argued that such a high level of public support placed significant pressure on companies to respond positively to shareholders' concerns.

As companies are under continued pressure to improve their environmental, social and governance disclosure and performance (Ho, 2013; Kolk, 2008), inclusion in a responsible investment index is becoming more prevalent (Curto \& Vital, 2014). Examples of prominent responsible investment indices in the global context include the Domini 400 Social Index, the FTSE4 Good Indices series and the Dow Jones Sustainability Indexes series. The JSE's Socially Responsible Investment (SRI) index was the first of its kind to be introduced in an emerging market. It is currently setting the standard for JSE-listed companies in terms of nonfinancial reporting (Maubane, Prinsloo \& Van Rooyen, 2014).

Several authors determined that large companies are mostly targeted (via the proxy voting process) due to their visibility (Nordén \& Strand, 2011; Poulsen et al., 2010) as are those that reported poor financial results in previous periods (Lantz, Montandrau \& Sahut, 2010; Ng, Wang \& Zaiats, 2009; Karpoff et al., 1996).

In the light of the typical factors that attract shareholder activism in the literature, the hypotheses as shown in Table 1 were formulated for empirical testing in the South African context. 
Table 1: Research hypotheses

\begin{tabular}{|c|c|c|}
\hline & Expected relationship & Relevant variables \\
\hline $\mathrm{H}_{1}$ : & $\begin{array}{l}\text { Companies excluded from the JSE SRI index attract significantly more } \\
\text { 'against' votes compared to those included in the index }\end{array}$ & Inclusion in the JSE SRI index in 2013 \\
\hline $\mathrm{H}_{2}:$ & $\begin{array}{l}\text { Companies with low ESG disclosure scores attract significantly more } \\
\text { 'against' votes than those with high ESG disclosure scores }\end{array}$ & ESG disclosure score in 2013 \\
\hline $\mathrm{H}_{3}:$ & $\begin{array}{l}\text { Companies with low corporate governance disclosure scores attract } \\
\text { significantly more 'against' votes than those with high corporate } \\
\text { governance disclosure scores }\end{array}$ & Corporate governance disclosure score in 2013 \\
\hline $\mathrm{H}_{4}:$ & $\begin{array}{l}\text { Larger companies attract significantly more 'against' votes than smaller } \\
\text { companies }\end{array}$ & $\begin{array}{l}\text { Company size in } 2013 \text { as control variable measured } \\
\text { by total assets and the three ratios: market - to - book } \\
\text { value, capital expenditure- to- total assets and long - } \\
\text { term debt -to-total assets }\end{array}$ \\
\hline $\mathrm{H}_{5}:$ & $\begin{array}{l}\text { Companies with poor prior accounting performance attract significantly } \\
\text { more 'against' votes than those with strong prior accounting performance }\end{array}$ & Four year average return on assets (ROA) \\
\hline $\mathrm{H}_{6}:$ & $\begin{array}{l}\text { Companies with poor prior market performance attract significantly more } \\
\text { 'against' votes than those with strong prior market performance }\end{array}$ & Four year average total return \\
\hline $\mathrm{H}_{7}:$ & Industries differ in their tendency to attract 'against' votes. & Industry classification \\
\hline
\end{tabular}

\section{Research design}

To address the research objectives of this study, both secondary and primary data were collected and analysed.

\section{Secondary data collection and analysis}

Proxy voting data for 2013 were collected from the websites of 17 investment management companies in the country. Investment management companies were selected in a purposeful way based on their size (and hence potential influence as shareholder activists) and the availability of proxy voting data. A total of 97 asset management companies operated in South Africa in 2013, managing approximately R5.6 trillion worth of assets (De Bruin, 2014). The 17 investment management companies selected for this study collectively managed approximately R5156.65 billion, representing 92 per cent of assets under management. Where data were not publicly available, it was requested directly from investment management companies. The majority of investment management companies in the sample (76.4\%) were PRI signatories on 31 December 2013.

The selected investment management companies voted on 24510 resolutions in 2013. For each resolution, the following data were captured in an Excel database:

- Name of the investment manager who voted on the resolution, e.g. Allan Gray.

- The share code of the JSE-listed company that tabled the resolution, e.g. SOL.

- Type of resolution, i.e. ordinary or special.

- Type of meeting where the resolution was tabled. Codes were assigned for the following types of meetings: annual general meeting, general meeting, extraordinary general meeting, scheme meeting and special meeting.

- Manager's vote. Codes were used to distinguish among three possible votes, namely for, against and abstain.

- Voting outcome. Codes were assigned to resolutions based on the outcome of the voting process, namely passed, rejected or withdrawn. Some of this data had to be sourced from RMB Custody and Trustee Services.

All resolutions that attracted 'against' votes were categorised into themes. Resolutions tend to be fairly uniform in purpose as listed companies need to adhere to the guidelines set out in the Companies Act (No. 71 of 2008), the JSE listings requirements and King III. Forty-two financial and corporategovernance categories emerged from this classification. Resolutions pertaining to preference shares, exchange traded funds, $\mathrm{N}$-shares and $\mathrm{B}$-shares were excluded from the study. For comparative purposes, only those resolutions tabled at AGMs in 2013 were analysed. A total of 347 JSE-listed shares were covered in the final analysis.

In line with $\mathrm{Ng}$ et al. (2009), the dependent variable was constructed by merging the forty-two original catgories of responses into six homogeneous classes and by tallying the percentage of voting asset managers who voted against the resolutions in each of the following categories: the election and re-election of directors; remuneration policy; fees and incentives; placing ordinary shares, preference shares or linked units under directors' control; issuing ordinary shares, preference shares or linked units; and repurchasing shares. The independent variables represent three categories of variables, namely index inclusion variables (JSE SRI Index, ESG disclosure score and the corporate governance disclosure score), historical performance related variables (return on assets and total industry adjusted returns), and sizerelated control variables (the market-to-book ratio, the capital expenditure-to-total assets ratio, the long-term debt-to-total assets ratio and the total assets). The selected four size-related control variables are typically used by researchers when evaluating proxy voting activity (e.g. Matvos \& Ostrovsky, 2010; Ng et al., 2009).

Details on the operationalisation of the independent variables are presented in Table 2. For the purpose of regression modelling all incomplete cases were deleted and outliers beyond two standard deviations in the residuals were deleted. 
Table 2: Operationalisation of the independent (including the control) variables

\begin{tabular}{|c|c|c|}
\hline Independent variables & Measurement & Data source(s) \\
\hline $\begin{array}{l}\text { Inclusion in the JSE SRI index in } \\
2013\end{array}$ & $\begin{array}{l}\text { A code of } 1 \text { was assigned to companies that were included in the index and a } \\
\text { zero to those that were excluded. }\end{array}$ & The JSE \\
\hline ESG disclosure score in 2013 & $\begin{array}{l}\text { This score ranged from zero to } 100 \text {. A score of zero indicated that the company } \\
\text { reported on some of the ESG criteria evaluated, but did not meet the } \\
\text { acceptability criteria. The higher the score, the more comprehensively the } \\
\text { company disclosed its ESG policies and practices. An 'N/A' indicated that the } \\
\text { company did not disclose any of the evaluated information in its } 2013 \text { annual } \\
\text { report. }\end{array}$ & Bloomberg \\
\hline $\begin{array}{l}\text { Corporate governance disclosure } \\
\text { score in } 2013\end{array}$ & The same interpretation as above. & Bloomberg \\
\hline Industry classification & $\begin{array}{l}\text { Resources; Basic materials; General industrials; Consumer goods; Consumer } \\
\text { services; Financials; Technology; AltX }\end{array}$ & The JSE \\
\hline $\begin{array}{l}\text { Four year average return on assets } \\
\text { (ROA) }\end{array}$ & Arithmetic mean of ROAs at financial year-end (2010, 2011, 2012 and 2013). & Bloomberg \\
\hline Four year average total return & $\begin{array}{l}\text { Arithmetic mean of the difference between a company's total return and its } \\
\text { industry's return on } 31 \text { December of each year }(2010,2011,2012 \text { and 2013). }\end{array}$ & $\begin{array}{l}\text { Bloomberg and the } \\
\text { JSE }\end{array}$ \\
\hline Market-to-book ratio in 2013 & Market capitalisation divided by book value of equity on 31 December 2013. & Bloomberg \\
\hline $\begin{array}{l}\text { CAPEX-to-total assets ratio in } \\
2013\end{array}$ & Capital expenditure divided by total assets on 31 December 2013. & Bloomberg \\
\hline $\begin{array}{l}\text { Long-term debt-to-total assets } \\
\text { ratio in } 2013\end{array}$ & Long-term debt divided by total assets on 31 December 2013. & Bloomberg \\
\hline Company size in 2013 & Log of total assets on 31 December 2013. & Bloomberg \\
\hline
\end{tabular}

Descriptive statistics were computed and the stated hypotheses were tested by means of stepwise multiple regression analysis using cross-sectional data.

\section{Primary data collection and analysis}

A number of informal telephonic and personal interviews were conducted with seven investment managers to gauge their views on the statistical findings of the study. These individuals were selected based on the extent to which their companies opposed management. This subjective selection criterion was based on the percentage of against votes they cast in 2013, public criticism levelled against JSE-listed companies in the media and the investment manager's reputation as shareholder activist.

Open-ended questions were posed to gain more insight into managers' views on proxy voting as a shareholder activism tool, the availability of their proxy voting policies and results and the proxy voting process followed in their respective companies. Some questions also centred on the effectiveness of proxy voting as a means to voice shareholder dissent, the need for shareholder activism in South Africa and suggestions to stimulate active engagement among institutional investors in the country. The qualitative data gathered during the interviews were coded and examined for recurrent patterns as well as inconsistencies.

\section{Empirical findings}

\section{Views on proxy voting as a shareholder activism tool}

Although all the investment managers who were interviewed deemed shareholder activism as an important responsible investment strategy, they had vastly different views on what the phenomenon exactly entailed. Several investment managers believed that shareholder activism consisted of proxy voting only, whereas others contended that proxy voting was only "the tip of the activism iceberg". The latter view is more in line with current thinking in that proxy voting is only one of the mechanisms that shareholders can use to voice their concerns. Although all 17 investment management companies had proxy voting policies at the end of 2013, just over half of these policies $(53 \%)$ were available online. Very few of these investment management companies (41\%) published their proxy voting results online, despite the fact that PRI signatories are required to make their proxy voting results available to the public. Those that did not publish their results online indicated that the results were available on request.

\section{The proxy voting process}

The interviews further revealed that proxy voting processes differed between the investment management companies. Whereas some of the managers delegated the responsibility of voting to analysts, others had dedicated teams allocated to this activity. The physical act of voting also ranged from capturing votes online, to electronically submitting votes to custodians and casting paper-based votes that were either scanned or faxed to custodians. Custodians confirmed that quite a large portion of votes was still paper-based. This process seems to be very inefficient and slow and poses the question whether these votes are monitored at all.

\section{Proxy voting results}

A summary of the 17 investment management companies' proxy voting results in 2013 is tabulated in Table 3. 
Table 3: Proxy voting results

\begin{tabular}{|c|c|c|c|c|c|c|}
\hline \multirow{2}{*}{ Investment management company } & \multirow{2}{*}{$\begin{array}{l}\text { No of JSE-listed companies } \\
\text { whose shares were voted on }\end{array}$} & \multicolumn{4}{|c|}{ Managers' votes } & \multirow{2}{*}{$\begin{array}{l}\text { 'Against' votes } \\
\text { as \% of total }\end{array}$} \\
\hline & & Abstain & Against & For & Total & \\
\hline Abax Investments & 8 & 0 & 12 & 139 & 151 & 7.9 \\
\hline Afena Capital & 40 & 4 & 69 & 855 & 928 & 7.4 \\
\hline Allan Gray & 77 & 37 & 90 & 1179 & 1306 & 6.9 \\
\hline Cadiz Asset Management & 25 & 0 & 48 & 470 & 518 & 9.3 \\
\hline Coronation Fund Managers & 339 & 4 & 125 & 5278 & 5407 & 2.3 \\
\hline Element Investment Managers & 46 & 22 & 161 & 631 & 814 & 19.8 \\
\hline Foord Asset Management & 6 & 0 & 21 & 54 & 75 & 28.0 \\
\hline Futuregrowth Asset Management & 5 & 1 & 1 & 62 & 64 & 1.6 \\
\hline Investec Asset Management & 57 & 22 & 42 & 993 & 1057 & 4.0 \\
\hline Kagiso Asset Management & 37 & 15 & 82 & 606 & 703 & 11.7 \\
\hline Old Mutual Investment Group (SA) & 146 & 427 & 135 & 2144 & 2706 & 5.0 \\
\hline Public Investment Corporation & 91 & 4 & 150 & 2206 & 2360 & 6.4 \\
\hline Prescient Investment Management & 78 & 0 & 104 & 1495 & 1599 & 6.5 \\
\hline Prudential Portfolio Managers & 50 & 0 & 67 & 572 & 639 & 10.5 \\
\hline Stanlib & 123 & 2 & 17 & 2252 & 2271 & 0.7 \\
\hline Taquanta Asset Managers & 133 & 2 & 192 & 2243 & 2437 & 7.9 \\
\hline Vunani Fund Management & 116 & 21 & 294 & 1160 & 1475 & 19.9 \\
\hline Total & & 561 & 1610 & 22339 & 24510 & \\
\hline Total as \% of all votes & & 2.3 & 6.6 & 91.1 & 100.0 & \\
\hline
\end{tabular}

An inspection of Table 3 shows that only 6.6 per cent of votes were against the resolutions tabled by JSE-listed companies. The investment managers interviewed attributed the low percentage of 'against' votes to successful private negotiations that took place with investee companies before their AGMs. As most of the investment managers' concerns had been adequately resolved before tabling, they voted in favour of the majority of proposals. Several of the investment managers emphasised that the low percentage of 'against' votes should not be interpreted as inactivity on their part, but that it was rather the result of proxy voting being "the last link in the engagement chain".

\section{Table 4: Corporate governance-oriented resolutions attracting 'against' votes}

\begin{tabular}{|c|c|c|}
\hline Resolution & $\mathbf{n}$ & $\%$ of all 'against' votes $(\mathrm{N}=1610)$ \\
\hline Approving the company's remuneration policy & 231 & 14.3 \\
\hline Re-electing a director & 188 & 11.7 \\
\hline Placing authorised, but unissued ordinary shares under directors' control & 184 & 11.4 \\
\hline Electing / re-electing audit committee member(s) ${ }^{(\mathrm{b})}$ & 107 & 6.6 \\
\hline Approving non-executive directors' remuneration / fees ${ }^{(a)}$ & 97 & 6.0 \\
\hline Approving / amending the share incentive plan ${ }^{(\mathrm{c})}$ & 27 & 1.7 \\
\hline Adopting a new memorandum of incorporation & 26 & 1.6 \\
\hline Other $\mathrm{r}^{(\mathrm{d})}$ & 21 & 1.3 \\
\hline Placing authorised, but unissued linked units under directors' control & 16 & 1.0 \\
\hline Amending the existing memorandum of incorporation & 15 & 0.9 \\
\hline Changing the notice period for general meetings & 11 & 0.7 \\
\hline Appointing / re-appointing independent external auditors & 10 & 0.6 \\
\hline Placing authorised, but unissued preference shares under directors' control & 9 & 0.6 \\
\hline Approving the chairperson's remuneration / fees ${ }^{(\mathrm{e})}$ & 8 & 0.5 \\
\hline Approving a share option plan for employees and managers & 7 & 0.4 \\
\hline Increasing the authorised ordinary share capital of the company & 5 & 0.3 \\
\hline Implementing resolutions passed at the annual general meeting & 5 & 0.3 \\
\hline Approving / adopting / amending the long-term incentive plan & 4 & 0.2 \\
\hline Making donations to political organisations and incurring political expenditure & 3 & 0.2 \\
\hline Approving amendments to the unit purchase trust scheme & 3 & 0.2 \\
\hline Electing a chairperson ${ }^{(\mathrm{e})}$ & 2 & 0.1 \\
\hline Receiving, considering and adopting the company's annual financial statements & 2 & 0.1 \\
\hline \multicolumn{3}{|c|}{ (b) In some cases, reference was made to the Audit Committee, whereas others referred to the Audit, Risk and Compliance Committee or the Audit and } \\
\hline \multicolumn{3}{|c|}{ (c) In some cases, the share incentive plan was called a share option plan or a share plan. It was not always specified whether the plan was a long-term } \\
\hline \multicolumn{3}{|c|}{$\begin{array}{l}\text { (d) incentive plan. } \\
\text { 'Other' resolutions included matters such as considering the social and ethics report and approving a scheme of arrangement. }\end{array}$} \\
\hline \multicolumn{3}{|c|}{ (e) Not all resolutions specified whether the chairperson was an executive or non-executive chairperson. As a result, no distinctiol } \\
\hline
\end{tabular}




\section{The nature of 'against' votes}

Given the well-developed corporate governance framework that exists in South Africa (Boshoff \& Schulshenk, 2014: 3), it came as no surprise that most of the 'against' votes focused on governance considerations (see Table 4). No resolutions about environmental or social considerations provoked 'against' votes in this sample.

The corporate governance resolution that attracted the most opposition was that of approving the remuneration policies of investee companies. At present, this vote remains a nonbinding, advisory vote. The status quo implies that remuneration committees do not have to change their remuneration policies even if more than 50 per cent of shareholders are opposed to it. This finding may be reflective of what Van Niekerk (2014) called a "mounting fury against the perceived exuberance of executive pay" in South Africa.

Although the endorsement of a company's remuneration policy is non-binding, research by Ernst \& Young in 2013 revealed that a large number of 'against' votes is a clear sign of shareholder discontent (Remuneration governance in South Africa - 2013 survey results, 2013). A third of the remuneration committees that participated in the Ernst \& Young study viewed an 'against' vote of 30 per cent or more as a warning signal, but only a fifth of these committees changed their remuneration policies in response to the 2013 non-binding vote. A growing interest in remuneration-related voting is also noted internationally (Armstrong, et al., 2013; Ferri \& Maber, 2013; Conyon \& Sadler, 2010).

Other corporate governance-oriented resolutions that attracted some opposition in 2013 involved the election and re-election of directors, particularly those serving on audit committees. Reasons for opposing these appointments included the lack of the independence of directors, and socalled 'over-boardedness' - a term describing directors who serve on several boards concurrently. Research in the US shows that shareholder activists have been quite effective in blocking the appointment of certain directors by 'just vote no' campaigns (Del Guercio, Seery \& Woidtke, 2008).

Table 5 illustrates that the majority of the financially-oriented resolutions that attracted opposition in 2013 centred on changes to the capital structures of investee companies, particularly in cases where managers sought approval to issue shares for incentive schemes. Shareholders in the US have voted against such proposals long before the current debate on appropriate executive remuneration (see for example Morgan \& Poulsen, 2001; Wagner \& Wagner, 1997).

Table 5: Financially-oriented resolutions attracting 'against' votes

\begin{tabular}{|c|c|c|}
\hline Resolution & $\mathbf{n}$ & \% of all 'against' votes $(\mathrm{N}=1610)$ \\
\hline Issuing ordinary shares for cash ${ }^{(\mathrm{a})}$ & 156 & 9.7 \\
\hline Issuing ordinary shares & 119 & 7.4 \\
\hline Repurchasing ordinary shares ${ }^{(b)}$ & 98 & 6.1 \\
\hline Providing financial assistance ${ }^{(c)}$ & 89 & 5.5 \\
\hline Not exerting pre-emption rights & 29 & 1.8 \\
\hline $\begin{array}{l}\text { Approving the issuing of shares to directors and/or prescribed officers under } \\
\text { the share incentive plan }\end{array}$ & 17 & 1.1 \\
\hline Issuing linked units for cash & 16 & 1.0 \\
\hline Issuing linked units & 12 & 0.7 \\
\hline Issuing ordinary shares for the purpose of share options & 10 & 0.6 \\
\hline Issuing preference shares & 9 & 0.6 \\
\hline Creating and issuing convertible debentures & 7 & 0.4 \\
\hline Repurchasing linked units & 4 & 0.2 \\
\hline \multicolumn{3}{|c|}{$\begin{array}{l}\text { (a) Four resolutions related to issuing shares, and to sell treasury shares, for cash were included in this category. } \\
\text { (b) No distinction was made between resolutions based on the percentage of shares to be repurchased. }\end{array}$} \\
\hline \multicolumn{3}{|c|}{$\begin{array}{l}\text { This category included resolutions involving financial assistance for directors, prescribed officers, employee share scheme beneficiaries and related or } \\
\text { interrelated companies. }\end{array}$} \\
\hline
\end{tabular}

The two largest industries in South Africa, namely the financial and resources industries, attracted the most 'against' votes in 2013 (31.1\% and $19.1 \%$ respectively).

\section{The impact of 'against' votes}

A very small percentage of 'against' votes resulted in the rejection $(2.7 \%)$ or the withdrawal $(2.7 \%)$ of resolutions. This finding should, however, be interpreted with caution. Investment managers indicated that resolutions were often withdrawn as a result of successful private negotiations, or, when it became apparent to management that the resolution would not be supported at the AGM.

\section{Characteristics of companies that attracted 'against' votes in 2013}

As indicated earlier, six resolution categories were created to establish whether shareholder activists targeted companies with certain characteristics. The dependent variable for each resolution category was the percentage of voting asset managers who voted against a particular resolution. An initial analysis, which comprised a single-factor analysis of 
variance, was undertaken to test whether the mean percentages of 'against' votes over the different JSE sectors were similar. No evidence was found of a significant JSE industry (sectoral) effect in the dependent variable in any of the response categories (at the five per cent level of significance). As such, no sectoral dummy variables were included in the explanatory model.

This analysis was followed by a multiple regression analysis utilising all independent and size-related control variables. The results yielded low overall explanatory power (determination coefficients) accompanied by numerous insignificant estimated coefficients, potentially caused by multicollinearity. To address this problem, a stepwise regression approach was followed using a forward stepping algorithm allowing variables into the final equation only if significant at the five per cent level. All regression results were inspected for normally distributed error terms using cumulative probability plots combined with residual outlier rejection (beyond two standard deviations) where required. Table 6 contains a summary of the statistically significant relationships observed.

\section{Table 6: Statistically significant relationships}

\begin{tabular}{|c|c|c|c|c|c|c|c|}
\hline \multirow[b]{2}{*}{ Resolution category } & \multicolumn{4}{|c|}{$\begin{array}{l}\text { Significant regression coefficients (p-values are indicated } \\
\text { in brackets) }\end{array}$} & \multirow[b]{2}{*}{$\mathbf{R}^{2}$} & \multirow[b]{2}{*}{$\begin{array}{l}\text { Sample } \\
\text { size }\end{array}$} & \multirow{2}{*}{$\begin{array}{l}\text { No of } \\
\text { observations } \\
\text { deleted }\end{array}$} \\
\hline & Intercept & $\underset{\text { index }}{\text { JSE }} \quad$ SRI & $\begin{array}{l}\text { ESG } \\
\text { disclosure } \\
\text { score }\end{array}$ & $\begin{array}{l}\text { Capex:TA } \\
2013\end{array}$ & & & \\
\hline $\begin{array}{l}\text { Electing and re-electing of } \\
\text { directors } \mathrm{a})\end{array}$ & 23.2937 & $\begin{array}{l}-6.6723 \\
(0.0098)\end{array}$ & & & 0.1309 & 50 & 4 \\
\hline Remuneration policy & 21.5804 & & & $\begin{array}{l}99.2818 \\
(0.0116)\end{array}$ & 0.1306 & 48 & 2 \\
\hline $\begin{array}{lll}\text { Issuing } & \text { ordinary } & \text { shares, } \\
\text { preference shares or linked } \\
\text { units }\end{array}$ & 41.4545 & & $\begin{array}{l}-0.4656 \\
(0.0379)\end{array}$ & $\begin{array}{l}124.7437 \\
(0.0451)\end{array}$ & 0.1823 & 35 & 0 \\
\hline $\begin{array}{l}\text { Placing ordinary shares, } \\
\text { preference shares or linked } \\
\text { units under directors' control }\end{array}$ & 38.3333 & $\begin{array}{l}-13.4443 \\
(0.0105)\end{array}$ & & & 0.1777 & 36 & 2 \\
\hline Fees and incentives ${ }^{(b)}$ & \multicolumn{7}{|c|}{ No significant variables } \\
\hline Repurchasing shares & \multicolumn{7}{|c|}{ No significant variables } \\
\hline \multicolumn{8}{|c|}{$\begin{array}{l}\text { (a) This category consisted of resolutions that dealt with the election and re-election of directors, including the chairperson and directors } \\
\text { serving on board committees. } \\
\text { (b) This category contained resolutions that dealt with the approval and/or amending of directors' fees and various executive incentive } \\
\text { schemes. }\end{array}$} \\
\hline
\end{tabular}

The findings in Table 6 suggest that companies included in the JSE SRI index provoked significantly fewer 'against' votes on proposals to elect directors and to place shares or linked units under the control of directors compared to those companies that were excluded from this index in 2013. Companies with high ESG disclosure scores in 2013 also attracted less opposition when seeking approval to issue more shares or linked units. The empirical evidence thus provides support for Hypotheses $\mathrm{H}_{1}$ and $\mathrm{H}_{2}$ and goes a long way in promoting integrated reporting among JSE-listed companies. The findings also provide support for the growing demand for ESG reporting among responsible investors.

In contrast to the extant literature, no significant relationships were observed among any of the other independent variables, nor were there any significant differences found between industries.

Inspection of Table 6 further reveals that companies with high ratios of capital expenditure to total assets attracted more 'against' votes (on remuneration policies and the issuance of shares) in 2013 compared to those with low ratios. This implies that top managers cannot use (CAPEX) growth as a justification for higher salaries and bonuses. In a qualitative sense, the results support the results of $\mathrm{Ng}$ et al. (2009) in so far as the equations suggest low explanatory power coupled with a substantive number of insignificant variables. Those results that are significant tend to confirm prior expectations in terms of the direction of causality. However, the firmperformance variables, specified as historical averages, could not achieve the significance of the time-specific values used by $\mathrm{Ng}$ et al. (2009) in the context of panel data. No support could therefore be found for hypotheses $\mathrm{H}_{3}$ and $\mathrm{H}_{5}$ to $\mathrm{H}_{7}$.

\section{Summary, conclusions and recommendations}

As elsewhere in the world, shareholder activism in South Africa is a valuable strategy available to responsible investors who want to monitor and influence corporate behaviour. By virtue of their size, institutional investors have a responsibility to encourage ethical and sustainable business practices. Although local institutional investors have a range of shareholder activism mechanisms at their disposal, most of them prefer to engage with investee companies behind closed doors. As in the UK, public forms of shareholder activism might be seen as too aggressive and counterproductive.

Consistent with the results of Winfield (2011), differences were also noted in the current study in terms of the proxy voting procedures, policies and philosophies used by local 
investment management companies. Although all 17 investment management companies in the current study had proxy voting policies at the end of 2013, only half of them published their policies online. Even fewer published their voting results online. In the spirit of CRISA, local institutional investors are encouraged to increase public disclosure of their proxy voting policies and results. It is also suggested that they publically disclose some details on the issues they raised in private with investee companies. Enhanced disclosure will not only improve transparency and accountability, but it will also go a long way in restoring trust in the financial industry.

Investment managers in the sample attributed the low level of 'against' votes in 2013 to successful private negotiations with investee companies. Acceptable assurances by investee companies to transform their business policies and practices could also explain why some resolutions were withdrawn prior to being put to a vote. Investment managers' claims challenge the notion that local shareholders are 'absent landlords' (Greenblo, 2014b; Mathews \& Hasenfuss, 2013; Barron, 2011; African Governance Report II 2009, 2009). More research is, however, required to verify this claim.

The empirical evidence suggests, as in the US and UK, South African shareholder activists are also beginning to take a more active interest in executive remuneration issues. A review of the international literature shows that remuneration-related activism has increased substantially after the 2008 global financial crisis (Bhagat \& Romano, 2009; Palmon, Santoro \& Strauss, 2009). Given that the vote to endorse a company's remuneration policy is non-binding, its effect is limited to signalling shareholder dissent. In the light of growing concerns about the wage gap in South Africa, it is recommended that the regulator investigate alternatives to the non-binding vote on remuneration (Crotty, 2014; Duncan, 2014). The regulator could change the non-binding vote to a binding vote as is the case in the UK, or introduce a 'two strikes' rule as in Australia (Delman, 2010).

Other resolutions, which attracted some opposition in 2013, centred on the election and re-election of directors, and changes to the capital structures of investee companies. The emphasis on corporate governance considerations, relative to environmental and social concerns, could be attributed to the world-class corporate governance framework that is in place in South Africa. It is, however, recommended that institutional investors devote more attention to environmental and social considerations as well.

In 2013, local shareholder activists targeted companies that were excluded from the JSE SRI index and those with poor ESG disclosure in a few categories. Companies that wish to avoid public shareholder hostility in future would thus do well by improving their non-financial reporting and appoint adequately qualified and experienced directors.

It is also recommended that more local shareholders, irrespective of their size, use the media to raise their concerns about unsustainable business practices. Valuable lessons can be learned from well-known individual shareholder activist
Theo Botha's endeavours in this regard (Steyn, 2011). In the UK, prominent investment managers also attribute their success as shareholder activists to using the media as an ally, and being transparent about their engagements.

Proxy voting procedures in South Africa seem to be inefficient as many investment management companies still conduct paper-based voting. A changeover to an electronic voting system is recommended.

It is expected that more shareholder activism will take place as local trustees begin to take an active interest in the phenomenon. In this study, it was found that a number of investment managers called on boards of trustees to invite them to discuss their engagement activities on a regular basis. It is foreseen that this kind of interaction will not only enhance transparency and accountability in the future, but will also lead to better long-term value creation for investors.

Although a few consulting companies (such as ISS Proxy Voting Services and Glass Lewis) already provide proxy voting advice to local institutional investors, more of these specialist services are necessary. It is further recommended that the Institute of Directors in Southern Africa consider designing a practical framework to enhance relationships with investors. The framework of the Australian Institute of Company Directors, for example, discusses the legal underpinnings governing the relationship between boards, shareholders and executives and provides guidance to institutional investors on creating effective communication strategies. Such a framework would, however, require local institutional investors to be exempt from collusion charges when collectively engaging with investee companies (Greenblo, 2014a).

Tertiary educators and training providers also have a responsibility to encourage responsible investment in South Africa. Not only should they create more awareness of responsible investment strategies among investment professionals, but they should also imbue decision-makers with the skills necessary for effective engagement. Finally, more research is required on the nature of private negotiations in South Africa. Particular attention should be given to the role of trade unions as shareholder activists.

In 2004, Finlay argued that responsible investment in South Africa was "a big boat that we're trying to row with little oars... and we've got a long way to go before we reach the harbour gates and high seas". Since then much has happened to shape the nature of responsible investment in the country (Viviers, 2014: 769). The findings of this study suggest that the tide might finally be turning in favour of greater responsible investment in South Africa, especially as far as shareholder activism is concerned.

\section{Acknowledgements}

The researchers would like to thank Ms Karlien de Bruin at Grayswan Investments, Ms Anika Berning and Mr Gerrit Marais for their valuable inputs in the study. 


\section{References}

Admati, A.R. \& Pfleiderer, P. 2009. "The "Wall Street Walk" and shareholder activism: Exit as a form of voice', The Review of Financial Studies, 22(7): 2645-2685.

African Governance Report II 2009. 2009. United Nations Economic Commission for Africa. [online] URL:http://www.uneca.org/sites/default/files/publications/agr2english.pdf

Aggarwal, R., Saffi, P.A. \& Sturgess, J. 2015. 'The role of institutional investors in voting: evidence from the securities lending market', The Journal of Finance, LXX(5): 2309-2345.

Armstrong, C.S., Gow, I.D. \& Larcker, D.F. 2013. 'The efficacy of shareholder voting: evidence from equity compensation plans', Journal of Accounting Research, 51(5): 909-950.

Barron, C. 2011. 'Roy McAlpine: A legend is getting off the bus', Times Live, 29 May, [online] URL:http://www.timeslive.co.za/business/2011/05/29/newsmakerroy-mcalpine-a-legend-is-getting-off-the-bus

Bauer, R., Moers, F. \& Viehs, M. 2012. 'The determinants of withdrawn shareholder proposals', Social Science Research Network, [online] URL:http://ssrn.com/abstract=1885392

Becht, M., Franks, J., Mayer, C. \& Rossi, S. 2010. 'Returns to shareholder activism: evidence from a clinical study of the Hermes UK Focus Fund', The Review of Financial Studies, 23(3): 30933129.

Bhagat, S. \& Romano, R. 2009. 'Reforming executive remuneration and committing to the long-term', Yale Journal on Regulation, 26(2): 359-372.

Boshoff, S. \& Schulshenk, J. 2014. 'Responsible investment - are South Africa's investors committed?', Trialogue, [online] URL:http://www.trialogue.co.za/wp-content/uploads/2014/06/FA_ Responsible-investment_final_lr.pdf

Cheng, C.S.A., Huang, H.H., Li, Y. \& Lobo, G. 2010. 'Institutional monitoring through shareholder litigation', Journal of Financial Economics, 95: 356-383.

Chung, H. \& Talaulicar, T. 2009. 'Forms and effects of shareholder activism', Corporate Governance: An International Review, 18(4): 253-257.

Clark, G.L. \& Hebb, T. 2004. 'Pension fund corporate engagement - the fifth stage of capitalism', Industrial Relations, 59(1): 142-171.

Code for Responsible Investing in South Africa. 2011. Association of Savings and Investments SA, July, [online] URL:http://asisa.co.za/asisadocs/CRISA\%20Code\%202011Final.p df

Conyon, M. \& Sadler, G. 2010. 'Shareholder voting and directors' pay report legislation: say on pay in the UK', Corporate Governance: an International Review, 18(4): 296-312.

Crotty, A. 2014. 'JSE proposes raft of changes to AGM requirements', Times Live, 13 April, [online] URL:http://www.timeslive.co.za/Feeds/2014/04/13/jse-proposesraft-of-changes-to-agm-requirements
Curto, J.D. \& Vital, C. 2014. 'Socially responsible investment: a comparison between the performance of sustainable and traditional stock indexes', Journal of Reviews on Global Economics, 3: 349363.

De Bruin, K. 2014. Personal communication. Senior investment analyst. Grayswan Investments, Somerset West, South Africa.

Del Guercio, D., Seery, L. \& Woidtke, T. 2008. 'Do boards pay attention when institutional investor activists "just vote no"?', Journal of Financial Economics, 90: 84-103.

Delman, J.R. 2010. 'Structuring say-on-pay: A comparative look at global variations in shareholder voting on executive compensation', Columbia Business Law Review, 2: 583-621.

Duncan, J. 2014. 'Country's shareholders need greater say on executive pay', Business Day, 22 July, [online] URL:http://www.bdlive.co.za/opinion/2014/07/22/countrysshareholders-need-greater-say-on-executive-pay

European SRI study 2014. 2014. EuroSIF, [online] URL:http://www.eurosif.org/wp-content/uploads/2014/09/EurosifSRI-Study-20142.pdf

Ferri, F. \& Maber, D.A. 2013. 'Say on pay votes and CEO compensation: Evidence from the UK', Review of Financial Studies, 17(2): 527-563.

Finlay, A. 2004. 'Investing in social responsibility', South Africa.Info, 20 August, [online] URL:http://www.southafrica. info/doing_business/economy/development/socialindex.htm

Gillan, S.L. \& Starks, L.T. 2000. 'Corporate governance proposals and shareholder activism: the role of institutional investors', Journal of Financial Economics, 57: 275-305.

Gillan, S.L. \& Starks, L.T. 2007. 'The evolution of shareholder activism in the United States', Journal of Applied Corporate Finance, 19(1): 55-73.

Greenblo, A. 2014a. 'The need for shareholder activism in retirement funds', Moneyweb, 18 September, [online] URL:http://www.moneyweb.co.za/moneyweb-soapbox/the-needfor-shareholder-activism-in-retirement-fu

Greenblo, A. 2014b. 'JSE companies' boards to be targeted', Moneyweb, 28 November, [online] URL:http://www.moneyweb.co.za/moneyweb-corporategovernance/jse-companies-boards-to-be-targeted

Hadani, M., Goranova, M. \& Khan, R. 2011. 'Institutional investors, shareholder activism and earnings management', Journal of Business Research, 64(12): 1352-1360.

Ho, M. 2013. 'The social construction perspective on ESG issues in SRI indices', Journal of Sustainable Finance and Investment, 3(4): 360-373.

Judge, W.Q., Guar, A., \& Muller-Kahle, M.I. 2010. 'Antecedents of shareholder activism in target firms: evidence from a multi-country study', Corporate Governance: an International Review, 18(4): 258-273.

Kaempfer, W.H., Lehman, J.A. \& Lowenberg, A.D. 2009. 'Divestment, investment sanctions, and disinvestment: an evaluation 
of anti-apartheid policy instruments', International Organization, 41(3): 457-473.

Karpoff, J.M., Malatesta, P.H. \& Walkling, R.A. 1996. 'Corporate governance and shareholder initiatives: empirical evidence', Journal of Financial Economics, 42: 365-395.

Kolk, S. 2008. 'Sustainability, accountability and corporate governance: exploring multinationals' reporting practices', Business Strategy and the Environment, 17(1): 1-15.

Lantz, J-S., Montandrau, S. \& Sahut, J-M. 2010. 'Activism of institutional investors, corporate governance alerts and financial performance', International Journal of Business, 15(2): 221-240.

Lee, M-D.P. \& Lounsbury, M. 2011. 'Domesticating radical rant and rage: an exploration of the consequences of environmental shareholder resolutions on corporate environmental performance', Business \& Society, 50(1): 155-188.

Lekhesa, M.W. 2009. Shareholder activism: The birth of a new phenomenon in South African corporate law. Unpublished Master's thesis. University of the Free State, Bloemfontein.

Mathews, C. \& Hasenfuss, M. 2013. 'Money talks', Financial Mail, 23 May, [online] URL:http://www.fm.co.za/business/money/ 2013/05/23/money-talks

Matthews, M. (Ed). 2014. The Trialogue 2014 CSI Handbook. 2014. $17^{\text {th }}$ Edition. Trialogue: Johannesburg.

Matvos, G. \& Ostrovsky, M. 2010. 'Heterogeneity and peer effects in mutual fund proxy voting', Journal of Financial Economics, 98(1):90-112.

Maubane, P., Prinsloo, A. \& Van Rooyen, N. 2014. 'Sustainability reporting patterns of companies listed on the Johannesburg Stock Exchange', Public Relations Review, 40: 153-160.

Morgan, A., Poulsen, A., Wolf, J. \& Yang, T. 2011. 'Mutual funds as monitors: evidence from mutual fund voting', Journal of Corporate Finance, 17(4): 914-928.

Morgan, A.G. \& Poulsen, A.B. 2001. Linking pay to performance compensation proposals in the S\&P 500. Journal of Financial Economics, 62(3): 489-523.

Ng, L., Wang, Q. \& Zaiats, N. 2009. 'Firm performance and mutual fund voting', Journal of Banking and Finance, 33(12): 2207-2217.

Nordén, L. \& Strand, T. 2011. 'Shareholder activism among portfolio managers: rational decision or 15 minutes of fame?', Journal of Management Governance, 15: 375-391.

Palmon, D., Santoro, M.A. \& Strauss, R. 2009. 'Pay now, lose later: the role of bonuses and non-equity incentives in the financial meltdown of 2007-2009', The Open Ethics Journal, 3: 76-80.

Poulsen, T., Strand, T. \& Thomsen, S. 2010. 'Voting power and shareholder activism: as study of Swedish shareholder meetings', Corporate Governance: An International Review, 18(4): 329-343.

Proffitt, W.T. (Jr) \& Spicer, A. 2006. 'Shaping the shareholder activism agenda: institutional investors and global social issues', Strategic Organisation, 4(2): 165-190.
Rademeyer, C. \& Holtzhausen, J. 2004. 'King II, corporate governance and shareholder activism', South African Law Journal, 120(4): $767-775$.

Rehbein, K., Waddock, S. \& Graves, S.B. 2006. 'Understanding shareholder activism: which corporations are targeted?', Business and Society, 43(3): 239-267.

Remuneration governance in South Africa - 2013 survey results. 2013. Ernest \& Young, [online] URL:http://www.ey.com/ Publication/vwLUAssets/Remuneration_Governance_in_South_Af rica/\$FILE/EY\%202103\%20Survey\%20Remuneration\%20Govern ance.pdf

Responsible investment research - CRISA disclosure by institutional investors and their service providers. 2013. CRISA Committee and E\&Y, [online] URL:https://c.ymcdn.com/ sites/iodsa.site-ym.com/resource/collection/951D7741-44CB4119-A107-1F502A9A6C96/7478_IoDSA_CRISA_Research_ Design_Digital_Version.pdf

Silverman, G. \& Duncan, J. 2014. 'Responsible investment - are South Africa's investors committed?', EY Trialogue Sustainability Forum, 28 August.

Sjöstrom, E. 2008. 'Shareholder activism for corporate social responsibility', Sustainable Development, 16(3): 141-154.

Sparks, R. \& Cowton, C.J. 2004. 'The maturing of socially responsible investment: a review of the developing link with corporate social responsibility', Journal of Business Ethics, 52(1): 45-57.

Steyn, L. 2011. 'Theo Botha - the shareholder activist', Mail \& Guardian, 13 May, [online] URL:http://mg.co.za/article/2011-0513-theo-botha-the-shareholder-activist

Thomas, R.S. \& Cotter, J.F. 2007. 'Shareholder proposals in the new millennium: shareholder support, board response, and market reaction', Journal of Corporate Finance, 13(2-3): 368-391.

Van Niekerk, R. 2014. 'Mind the (wage) gap', Moneyweb, 21 May, [online] URL:http://www.moneyweb.co.za/moneyweb-southafrica/mind-the-wage-gap

Veitch, M. C. 1995. The role of institutional investors towards critical issues of corporate governance in South Africa. Unpublished MBA thesis. University of Stellenbosch Business School, Stellenbosch.

Viviers, S. 2014. '21 years of responsible investing in South Africa: key investment strategies and criteria', Journal of Economic and Financial Sciences, 7(3): 737-771.

Wagner, R.H. \& Wagner, C.G. 1997. 'Recent developments in executive, director, and employee stock compensation plans: new concerns for corporate directors', Stanford Journal of Law, Business \& Finance, 3(1): 5-25.

Wen, S. 2009. 'Institutional investor activism on socially responsible investment: effect and expectations', Business Ethics: A European Review, 18(3): 308-333.

Willard T., Carleton, W.T., Nelson, J.M. \& Weisbach, M.S. 2002. 'The influence of institutions on corporate governance through private negotiations: evidence from TIAA-CREF', The Journal of Finance, 53(4): 1335-1362. 
Winfield, J. 2011. 'The landscape of proxy voting at South African asset managers', RisCura, [online] URL:http://www.riscura.com/ docs/research/SpoiltVotesHigh_Aug2011.pdf

Wu, L. 2004. 'The impact of public opinion on board structure changes, director career progression, and CEO turnover: evidence from CalPERS' corporate governance program', Journal of Corporate Finance, 10(1): 199-227. 